\title{
Effect of Fungicide Seed Treatment on Field Emergence of Poor and Good Quality Pigeon Pea (Cajanus cajan) ${ }^{1}$
}

\author{
M. A. Ellis, R. S. Smith, and O. Zambrano \\ ABSTRACT
}

Poor quality $(50 \%$ seed germination in vitro and $67 \%$ of seeds infected by internally seedborne fungi) and good quality ( $93 \%$ seed germination in vitro and $9 \%$ of seeds infected by internally seedborne fungi) seed lots of pigeon pea (cultivar 2-B Bushy) were treated with fungicides, penicillin-G, and penicillin-G plus fungicide. All treatments significantly increased percentage field emergence of the poor quality seed lot above the nontreated control. There was no significant difference in percentage field emergence between treated and nontreated seeds of the good quality seedlot.

When surface disinfested, poor quality seeds were treated with thiram and placed on potato dextrose agar, the percentage seed germination in vitro increased significantly, and percentage incidence of internally seedborne fungi decreased significantly compared to that of the nontreated control.

\section{INTRODUCTION}

Studies on soybean (Glycine max) and dry bean (Phaseolus vulgaris) have shown that fungicide seed treatment is beneficial in increasing stands when the quality of the seeds being treated is low (low percentage seed germination and high percentage of internally seedborne fungi). When high quality (high percentage seed germination and low percentage internally seedborne fungi) seed are treated, no or very few beneficial results have been reported $(3,4,5,6)$. This indicates that internally seedborne fungi are an important factor in decreasing the germination and field emergence of soybean and dry bean.

One of the factors limiting increased production of pigeon pea in Puerto Rico is poor germination and emergence in the field. In commercial plantings grown in 1976 in cooperation with local growers, field emergence of 4-ha fields ranged from 28 to $45 \%$. In vitro germination percentage and incidence of internally seedborne fungi of the seeds used in planting these fields were 60 and $75 \%$, respectively. When these seeds were treated with fungicide, the recovery of internally seedborne fungi was reduced and in vitro germination was increased (2). This indicates that internally seedborne fungi play a major role in reducing the quality of pigeon pea seed in Puerto Rico.

Little has been published on the control of internally seedborne fungi

'Manuscript submitted to editorial Board March 2, 1978.

${ }^{2}$ Assistant Professor of plant pathology, Department of Crop Protection, University of Puerto Rico; Assistant Professor, Department of Agronomy, University of Illinois; and Graduate Assistant, Department of Crop Protection, College of Agricultural Sciences Mayagüez Campus, University of Puerto Rico, respectively. 
and the use of fungicide seed treatment on pigeon pea (1). This paper reports the effect of fungicide seed treatments on field emergence of poor and good quality pigeon pea seed.

\section{MATERIALS AND METHODS}

Two seed lots of pigeon pea (cultivar 2-B Bushy) were selected for this study. High quality seeds were produced at the Fortuna Substation of the Agricultural Experiment Station of the University of Puerto Rico. Poor quality seeds were produced at the Isabela Substation. Both seed lots were produced in the 1976-1977 growing season. In order to determine the percentage germination and internally seedborne fungi, 400 seeds from each lot were surface disinfested by being soaked in a $0.25 \%$ sodium hypochlorite solution for $2.5 \mathrm{~min}$, and then in $70 \%$ ethanol for $2 \mathrm{~min}$, and finally being rinsed in sterile distilled water. Seeds were then plated on Difco potato-dextrose agar (PDA) in culture plates (four seeds per plate) and incubated at $25 \mathrm{C}$. After 7 days, the percentage recovery of internally seedborne fungi and in vitro germination were recorded.

Seeds from each lot were treated with the following fungicides: thiram ${ }^{3}$ [tetramethylthiuram disulfide, E.I. Dupont's Arasan 50\% wettable powder]; captan [N-(trichloromethyl-thio)-4-cyclohexene-1, 2 dicarboximide) Chevron's Orthocide 50\% wettable powder]; carboxin [5,6-dihydro-2methyl-1,4-oxathiin-3-carboxonilide, Uniroyal's Vitavax 34\% flowable]; captafol [cis-N (1,1,2,2-tetrachloroethyl) thio-4-cyclohexene-1,2-dicarboximide, Chevron's Difolitan 4F]; thiabendazole [2-(4-thiazolyl) benzimidazole, Merck \& Companies Mertect LSP 30\%]; chloroneb [1,4-dichloro2,5-dimethoxybenzene, E.I. Dupont's Demosan 65\% wettable powder]; and Uniroyal's experimental fungicide UBI-1127 (information on composite not available).

All fungicides were applied at the rate of $2.5 \mathrm{~g} / \mathrm{kg}$ of seed. Seeds treated with potassium penicillin-G were soaked for one hour in a solution of $1000 \mu \mathrm{g}$ penicillin-G per $\mathrm{ml}$ of dichloromethane (DCM) (7). After soaking, seeds were air dried for two hours, then either treated or nontreated with thiram. Seeds were treated in 100-seed lots on July 10 and planted in the field at the Isabela substation 3 days later. Treatments were arranged in a randomized complete block design with 3 replications of 100 seeds per each $6.1 \mathrm{~m}$ row. Stand counts were recorded 20 days after planting. Analysis of variance was calculated for percentage field emergence.

For determination of the effect of the fungicide seed treatment on the recovery of internally seedborne fungi, three replications of 100 seed from

\footnotetext{
${ }^{3}$ Trade names are used in this publication solely for the purpose of providing specific information. Mention of a trade name does not constitute a guarantee or warranty of equipment or materials by the Agricultural Experiment Station of the University of Puerto Rico or an endorsement over other equipment or materials not mentioned.
} 
each seed lot were surface disinfested as previously described and treated with a slurry of thiram at the rate of $2.5 \mathrm{~g} / \mathrm{kg}$ of seed. Treated seeds were then placed on PDA as previously described and incubated at $25 \mathrm{C}$. After 7 days, the percentage recovery of fungi and germination in vitro were recorded. Surface disinfested but nontreated seeds of each seed lot served as controls. Analysis of variance for percentage recovery of total fungi, recovery of fungi by genera, and germination in vitro was calculated for the completely randomized design used.

\section{RESULTS}

In vitro ( $\mathrm{PDA}$ ) assays showed that the percentage germination and total internally seedborne fungi for the poor quality seedlot were $50 \%$ and $67 \%$, respectively. The following genera of fungi with their mean percentage occurrence were isolated from the poor quality seed lot: Lasiodiplodia theobromae (15\%); Alternaria tenuissima (10\%); Fusarium semitectum (17\%); Phomopsis sp. (16\%); and miscellaneous fungi (9\%). When poor quality seeds were treated with thiram and placed on PDA, percentage germination, occurrence of total internally seedborne fungi and occurrence of fungi by genera, respectively, were $76 ; 14 ; L$. theobromae (4\%); A. tenuissima (3\%); F. semitectum (4\%); Phomopsis sp. (3\%); and miscellaneous fungi $(0)$.

Treatment of poor quality seeds resulted in a significantly higher $(0.01$ level) in vitro germination percentage, and a significantly lower occurrence of total internally seedborne fungi.

The percentage in vitro germination and occurrence of internally seedborne fungi for the good quality seed lot were $93 \%$ and $9 \%$, respectively. Aspergillus sp. was the only fungus isolated from good quality seeds. When good quality seeds were treated and placed on PDA, the percentage germination and occurrence of fungi, respectively, were $95 \%$ and Aspergillus sp. 3. There was no significant increase in seed germination when high quality seeds were treated.

All treatments of good quality seeds and the nontreated control had a percentage field emergence of at least $90 \%$ at 20 days after planting (table 1). There were no significant differences between any treatments and the control or between treatments alone in percentage emergence for good quality seeds. For poor quality seeds, all treatments had a significantly higher percentage field emergence than the nontreated control (table 1). Captan, thiram, thiram + penicillin-G, UBI 1127, captafol and thiabendazole gave a significantly higher percentage field emergence than the remaining treatments. Carboxin and chloroneb had a significantly higher percentage emergence than penicillin-G alone. 


\section{DISCUSSION}

The results of this study showed no beneficial effect for fungicide treatment on high quality pigeon pea seeds. However, when low quality seeds with a high percentage of internally seedborne fungi were treated and planted in the same field plot, the percentage emergence was significantly increased over that of the control for all treatments.

The nontreated high quality seeds had a percentage emergence of $91 \%$ at 20 days after planting. Due to this high percentage emergence of nontreated seeds, there appeared to be no problems with emergence related to soil-borne fungi attacking the seeds. In the same field plot, the percentage emergence was $45 \%$ for nontreated poor quality seeds. When

TABLE 1.-Effect of chemical seed treatment on percent field emergence of poor and good quality pigeon pea seed

\begin{tabular}{|c|c|c|c|}
\hline \multirow[b]{2}{*}{ Treatment } & \multirow[b]{2}{*}{ Rate product/kg seed } & \multicolumn{2}{|c|}{ Mean field emergence ${ }^{2}$} \\
\hline & & $\begin{array}{l}\text { Poor quality } \\
\text { seed }\end{array}$ & Good quality seed \\
\hline & & $\%$ & $\%$ \\
\hline Thiram & $2.5 \mathrm{~g}$ & 69.0 & 93.0 \\
\hline Thiram & $2.5 \mathrm{~g}$ & 70.3 & 93.7 \\
\hline+ penicillin-G + DCM ... & 1000 units/ml DCM & & \\
\hline Carboxin $\ldots$ & $2.5 \mathrm{~g}$ & 61.3 & 92.0 \\
\hline Captan .. & $2.5 \mathrm{~g}$ & 71.0 & 94.0 \\
\hline UBI 1127 & $2.5 \mathrm{~g}$ & 68.3 & 90.3 \\
\hline Captafol ............ & $2.5 \mathrm{~g}$ & 67.3 & 96.0 \\
\hline Penicillin-G + DCM & 1000 units/ml DCM & 51.0 & 92.7 \\
\hline Thiabendazole . . . . . . . . & $2.5 \mathrm{~g}$ & 68.0 & 91.7 \\
\hline Chloroneb ............. & $2.5 \mathrm{~g}$ & 66.0 & 90.0 \\
\hline Nontreated control $\ldots$ & & 45.0 & 91.3 \\
\hline LSD .05 & & 4.36 & N.S.D. \\
\hline LSD .01 & & 5.97 & \\
\hline
\end{tabular}

\footnotetext{
${ }^{1}$ Cultivar 2-B Bushy.

${ }^{2}$ Based on 3 replications of 100 seeds each for good and poor quality seeds. Emergence in the field was recorded 20 days after planting.
}

these seeds were treated with fungicides, emergence was increased by as much as 26\%. This indicates that the beneficial effects of the fungicides used in this study were not against soil-borne fungi, but against seedborne fungi.

When surface disinfested, poor quality seeds were treated with thiram and placed on PDA, the percentage germination was significantly increased and percentage occurrence of internally-borne fungi was significantly decreased. The observed increase in percentage field emergence and germination in vitro for treated seeds indicates that internally 
seedborne fungi are an important factor causing the reduction in pigeon pea seed germination and field emergence. The increased emergence for seeds treated with penicillin-G suggests that bacteria may also play some role in decreasing the field emergence of pigeon pea.

This study indicates that the most efficient method of obtaining a high percentage emergence and stand in the field is the planting of high quality seeds which are free of seedborne fungi and other disease-causing agents. When it becomes necessary to use poor quality seeds for planting, the use of seed treatment fungicides could be beneficial in obtaining satisfactory stands in the field.

These results are very similar to those reported from similar studies on soybean and dry bean $(3,4)$.

\section{RESUMEN}

Lotes de semillas de mala calidad de guandul del cultivar 2-B Bushy (50\% de germinación in vitro y $67 \%$ de las semillas infectadas internamente con hongos) y de buena calidad (93\% de germinación y $9 \%$ de infección), fueron tratados con fungicidas, penicilina$\mathrm{G}$ y penicilina-G más fungicida. Las semillas de mala calidad que recibieron cualquiera de estos tratamientos tuvieron un porcentaje de germinación en condiciones de campo significativamente mayor que las no tratadas. No hubo diferencias en porcentaje de emergencia entre las semillas de buena calidad tratadas y sin tratar.

Cuando las semillas de mala calidad, se trataron superficialmente, con thiram y colocadas en un medio de cultivo agar con papa y dextrosa, el porcentaje de germinación in vitro aumentó significativamente y la incidencia de hongos internos disminuyó también significativamente en comparación con las no tratadas.

\section{LITERATURE CITED}

I. Barnes, R. F. 1973. A preliminary list of literature on pigeon pea [Cajanus cajan (L.) Millsp.] - Plant Pathology. Univ. West Indies, Dep. Biol, Sci. Bull. No. I.

2. Ellis, M. A., Foor, S. R., and Meléndez P. L., 1977. Effect of internally seedborne fungi on germination of pigeon pea in Puerto Rico, Mem. Soc. Puertorriquena Cien. Agri., 2:8-9.

3. - Gálvez, G. E., and Sinclair, J. B. 1977. Efecto del tratamiento de semillas de frijol (Phaseolus vulgaris) de buena y mala calidad sobre la germinación bajo condiciones de campo, Turrialba 27: 37-39.

4. - Ilyas, M. B., and Sinclair, J. B.; 1975. Effects of three fungicides on internally seed-borne fungi of soybean seeds. Phytopathology 65: 553-556.

5. Johnston, A., 1951. Soybean seed treatment, Soybean Dig. 11: 17-20.

6. Mengistu, A., Ellis, M. A., Royce, D. J., and Sinclair, J. B., 1975. Soybean seed treatment studies. Fungi.-Nemat. Test Results of 1974, 30: 148-149.

7. Royce, D. J., Ellis, M. A., and Sinclair, J. B., 1975. Movement of penicillin into soybean seeds using dichloromethane, Phytopathology 65: 1319-1320. 